\title{
The emergence of endocrinology
}

\author{
by Richard B. Welbourn
}

\section{SUMMARY}

Endocrinology was recognized as a new branch of biological science mainly as a result of events which took place between about 1890 and 1905, but ideas and discoveries dating from antiquity contributed to it also. Experiments supporting the concept of internal secretions by the testicles were described by Aristotle (4th $\mathrm{c}$. B. C.) and by Hunter (18th c.) and Berthold (19th c.). In 1855 Bernard described glucose as an internal secretion of the liver and Addison reported the effects of adrenal disease in man. Adrenalectomy was fatal in animals. Goitre was known in antiquity and cretinism had been described by Paracelsus. Myxoedema was reported by Gull in 1873, and Kocher described cachexia strumipriva in 1883. In 1888 cretinism, myxoedema and cachexia strumipriva were attributed to thyroid insufficiency. In the 1890s Gley found that tetany after thyroidectomy was due to removal of the parathyroids. In 1884 Rehn proposed that toxic goitre was due to thyroid excess. In 1889 Brown-Séquard claimed that injections of testicular extract rejuvenated the elderly, and in 1893 he introduced organotherapy. In 1891 Murray treated myxoedema successfully with thyroid extract. In 1893 Oliver and Schäfer found that an adrenal extract raised the blood pressure, and soon adrenaline was extracted from the adrenal medulla. Adrenocortical deficiency was proposed as the cause of Addison's disease, and in 1896 Osler prepared an extract which relieved one patient. Diabetes mellitus, described in the first century, was usually fatal. Thirst and polyuria followed experimental pancreatectomy, and pancreatic lesions were found in some human diabetics. In the 19th century workers in France and Germany found that diabetes resulted from absence of an internal secretion by the islets of Langerhans and, in 1893, Laguesse described the function of the islets as "endocrine". In 1895 Beatson treated advanced breast cancer successfully by oöphorectomy. In 1895 Schäfer commended study of the internal secretions to physiologists. In 1902 Bayliss and Starling discovered secretin, a chemical messenger secreted by the intestinal mucosa. In 1905 Starling proposed the name "hormone" for this class of internal secretions. By then endocrinology had been launched as a new branch of science. 
The crucial events which led to the recognition of endocrinology as a new branch of biological science took place between about 1890 and 1905. Many ideas and discoveries dating from antiquity and apparently unrelated at first had, however, contributed to it.

Most of the organs and tissues that form the endocrine system were recognized over 100 years ago ${ }^{\text {la }}$. By about 1600 the gonads, pituitary, and adrenals had been described, and goitres were known to arise in the thyroid. In the 19th century the parathyroids, Leydig cells, islets of Langerhans, chromaffin cells in the gut and parafollicular cells of the thyroid were discovered. Several other microscopic endocrine tissues have been identified more recently.

The functions of all these organs remained unknown and were subject to much uninformed speculation for centuries. In the 18th century two interesting general hypotheses were proposed ${ }^{2 \mathrm{a}}$. In 1766 Albrecht von Haller (1708-77) suggested that the thyroid, the thymus and the spleen were glands without ducts, pouring special substances into the circulation, and others included the lymph nodes in this category. Soon after, in 1775, Théophile de Bordeu (1722-76; medical practitioner, Paris) proposed that all the organs of the body discharged into the blood "emanations" which were necessary and useful to the whole body.

\section{Internal secretions}

The first experimental observations which supported the idea of internal secretions were made on the testicles and the secondary sex characters. The effects of castration in animals and men (but not in women) had been known in prehistoric times and were described by Aristotle (384-322 B. C. $)^{3}$. In the 18th century, John Hunter (1728-93; surgeon and biologist, London) castrated cockerels, replaced their testicles in the abdomen, and found that the male secondary sex characters depended on the presence of viable testes ${ }^{4}$. His main interest, however, was in the vital force which allowed organs to be transplanted, not in the relationship between primary and secondary sex characters. In 1849 Arnold Berthold (1803-61; physician and biologist, Göttingen) confirmed Hunter's findings and concluded that the testes controlled the development of secondary sex characters through their influence on the blood ${ }^{4}$. Hunter's and Berthold's work was extremely pertinent to much that was undertaken in the second half of the nineteenth century, but 
was strangely overlooked until 1910, and played no part in the general development of endocrinology until then.

Claude Bernard (1813-78; Professor of Physiology, Collège de France, Paris) first actually observed internal secretion by an organ when he discovered, in 1855, that glucose was synthesized by the liver and secreted into the portal vein $^{2 \mathrm{~b}}$. He described this secretion as internal to distinguish it from bile, which he called the external secretion of the liver. The idea of internal secretions, which had been speculative before, now had a firm basis.

\section{The adrenals}

In the same year, 1855, attention was suddenly focused on the adrenals, when Thomas Addison (1793-1860; physician, Guy's Hospital, London) published his book On the constitutional and local effects of disease of the suprarenal capsules ${ }^{5}$. The clinical features included bronzing of the skin, and the adrenals showed gross disease, usually tuberculous. Adrenal atrophy was seen in one case. This work attracted much attention, especially in France, where the syndrome was named "Addisons's disease". The next year Charles Édouard Brown-Séquard (1817-94; physiologist, Paris) found that bilateral adrenalectomy in many animals was fatal, and he likened their condition to that of patients dying from Addisons's disease ${ }^{6}$. He concluded that the adrenals were essential to life, but adrenal insufficiency was not accepted as the cause of the disease until the end of the century, when other endocrine deficiency states were being proposed also.

\section{The thyroid - hypothyroidism}

Disease of the thyroid claimed attention next. Goitres were known in antiquity, and cretinism, associated with endemic goitre, was described by Paracelsus (1493-1541) in the 16th century ${ }^{\text {a a }}$. Goitre and cretinism had both been attributed to iodine deficiency, but nothing definite was known of their causes. In 1873 William Gull (1816-90; physician, Guy's Hospital, London) described a cretinous state in adults, which was later named myxoedema ${ }^{7 b}$. At this time surgical operations for the relief of life-threatening goitres were undertaken quite commonly, especially in the goitrous regions of central Europe. Previously nearly half the patients died from sepsis and bleeding. By about 1880, however, antisepsis and effective haemostasis were coming into use and, in the hands of Theodor Kocher (1841-1917) and some others, 
nearly 90 percent of patients survived operations for simple goitre ${ }^{\mathrm{lb}}$. For technical reasons, it was sometimes necessary to remove the whole of the thyroid gland to relieve obstruction of the trachea and oesophagus. In 1883 Kocher found that most patients treated in this way had developed "cachexia strumipriva", which he likened to cretinism in children ${ }^{8}$. Others described it as "operative myxoedema" in adults". The same year Felix Semon (1848-1921; German-born laryngologist, St.Thomas' Hospital, London) proposed that cretinism, myxoedema and cachexia strumipriva were all associated with absence or degeneration of the thyroid ${ }^{10}$. His remarks were treated with polite scepticism, but a myxoedema committee, under the chairmanship of William Ord (1834-1902; physician, St. Thomas' Hospital, London) was set up to investigate the matter ${ }^{11}$. Reports of many patients were analysed and the effects of thyroidectomy in animals were studied. This operation had been performed previously, with inconclusive results, but in the 1850s Moritz Schiff (1823-96; Professor of Comparative Anatomy, Berne) had found that it caused fatal tetany ${ }^{12}$. In 1884, after cachexia strumipriva had been described, Schiff (now Professor of Physiology, Geneva) repeated his experiments and found that death could be prevented by grafting the thyroid into the abdomen. He suggested that injection of thyroid extract would have the same effect, but he did not try it ${ }^{13}$. Others gave it intravenously, but found it toxic. Victor Horsley (1857-1916; surgeon and physiologist, University College, London), who was a member of Ord's committee, undertook thyroidectomy in monkeys the same year and observed acute muscular twitchings and convulsions at first, and myxoedema later ${ }^{12}$. He concluded that the effects of thyroidectomy in man were due to arrest of thyroid function, fully endorsing Semon's view, and in 1888 the myxoedema committee agreed ${ }^{11}$.

\section{The parathyroids}

The human parathyroids had been described in man by Ivar Sandström (1852-89; medical student, Uppsala) in $1880^{14}$, but it was not until they were rediscovered and studied physiologically in the 1890s by Eugène Gley (18571930; Professor of General Physiology, Collège de France, Paris) and by others in Italy, that the acute effects of thyroidectomy (as observed by Schiff and Horsley) were recognized as due to simultaneous, inadvertent parathyroidectomy ${ }^{1 \mathrm{lc}, 15}$. Tetany sometimes followed thyroidectomy in patients also, for the same reason. 


\section{Hyperthyroidism}

Soon after thyroid insufficiency had been recognized, excessive thyroid secretion was proposed as another cause of disease. Exophthalmic or toxic goitre had been described posthumously by Caleb Parry (1735-1822 ; physician, Bath) in $1825^{7 \mathrm{c}}$. It was clear, in retrospect, that some patients who underwent operation for goitre had been toxic, and in 1884 Ludwig Rehn (1849-1930; surgeon, Frankfurt am Main), reported three patients who were relieved of dyspnoea, and also of their toxic symptoms, by thyroidectomy ${ }^{16}$. He suggested, quite reasonably, that overactivity of the thyroid was responsible for the condition, but the idea of hyperthyroidism remained controversial for some years.

\section{Organotherapy}

In 1889, one year after the publication of the myxoedema committee's report, an extraordinary claim was made by Brown-Séquard, who was now aged 72 and respected internationally as a scientist. Twenty years earlier he had proposed intravenous injection of sperm to prevent senility, and now he reported that he had rejuvenated himself mentally and physically with injections of canine testicular extracts ${ }^{17}$. This announcement was viewed with contempt by most scientists, but at the same time it stimulated great interest concerning internal secretions in general.

Animal tissues had been used therapeutically from early times, and organs, whose defective functions were thought to cause disease, were given by mouth. Brown-Séquard apparently did not know of Hunter's and Berthold's work on testicular transplantation, which would have given strong support to his case. In 1893 he and his assistant, Arsène D'Arsonval (18511940 ; assistant to Brown-Séquard) went on to claim that administration of extracts from the testicles and from many other tissues were remarkably beneficial in many diseases ${ }^{18}$. Bovine testicular extracts were particularly potent and were said to cure or greatly ameliorate senile debility, locomotor ataxia, pulmonary tuberculosis, leprosy, malignant ulcers, Addison's disease, malaria and many other conditions.

Brown-Séquard proposed that lack of secretions caused disease and that important therapeutic effects would be obtained if the products of animal glands were given to people suffering from their deficiency. This was a valid hypothesis that he could have tested, but he failed to do so. His claims were 
accepted uncritically and were apparently substantiated by many others. This new therapeutic method was called organotherapy and was exploited by many physicians, quacks and pharmaceutical firms for another 40 years.

Endocrinology, which began to emerge at this time, was confused with it and, as a result, was later said to have suffered obstetric deformation at its very birth. Clinical endocrinology took many years to achieve respectability.

\section{Treatment of myxoedema}

Meanwhile work on the thyroid continued ${ }^{13}$. In 1889 treatment of myxoedema by transplantation of sheep's thyroid was attempted in Lisbon. There was some brief improvement, which was attributed to absorption of juice from the graft. A simpler form of treatment, however, was soon discovered. This was probably prompted by Brown-Séquard's organotherapy, but had a solid scientific basis. In 1891, at Horsley's suggestion, George Murray (18651939; physician, Newcastle-upon-Tyne) prepared a glycerine extract of sheep's thyroid, which he injected into a myxoedematous woman, who promptly improved ${ }^{19}$. Others tried it also, and reported favourably. The next year (1892), however, oral therapy with sheep's thyroid proved equally effective ${ }^{20}$ and was adopted widely and successfully for the treatment of myxoedema, cretinism, and cachexia strumipriva. Murray's replacement therapy was criticized because of its apparent similarity to organotherapy, but it survived on its scientific merit. His first patient remained well for 28 years ${ }^{\text {td. }}$.

Horsley and Murray were good scientists, but they were also very lucky. The thyroid is the only gland which stores large amounts of its hormones and, being aminoacids, they are soluble in water and are absorbed unchanged from the gut.

\section{Addison's disease and adrenaline}

Addison had found adrenal atrophy in one of his patients and, in the 1880s and $1890 \mathrm{~s}$, atrophy of the cortex, uncomplicated by tuberculosis, which destroys the medulla also, was recognized in many Addisonian patients. Walter Hadden (1856-93; physician, St. Thomas' Hospital, London) likened the histology of this lesion to that of the thyroid in myxoedema, and suggested that Addison's disease might similarly result from deficiency of an internal secretion ${ }^{2 c}$. 
In 1893 George Oliver (1841-1915; medical practitioner, Harrogate), who knew of Brown-Séquard's claims, prepared extracts of various tissues in glycerine and studied them physiologically in man with instruments that he had devised himself ${ }^{21}$. He found an adrenal extract that appeared vasoactive when given by mouth to his son, and hoped that it might prove effective in Addison's disease. However, he wanted it to be assessed by a professional physiologist, and took a sample to Edward Schäfer (later Sharpey-Schäfer, 1850-1935; Professor of Physiology, University College, London) ${ }^{22}$. Schäfer was irritated by Oliver's intrusion, but agreed to inject it intravenously into a dog, when he had finished another experiment. Much to his surprise the blood pressure rose dramatically. Oliver and Schäfer then investigated the extract together and found that it was derived from the adrenal medulla. Its actions included arteriolar constriction and rapid, forcible beating of the heart. This finding attracted great interest, and within 10 years 'adrenaline' was analyzed and synthesized in the United States. It was the first secretion of a ductless gland to be characterized chemically. Unfortunately it was ineffective in Addison's disease, but in 1896 William Osler (1849-1919; then Professor of Medicine, Johns Hopkins Hospital, Baltimore), prepared glycerine extracts of pigs' adrenals and gave them by mouth to several Addisonian patients, with apparent success in one case ${ }^{23}$. Transplantation of canine adrenal tissue was attempted also in Addisonian patients, but without benefit ${ }^{\text {ld }}$. The adrenal cortex and medulla, which had long been recognized as separate anatomically, were now seen to be functionally distinct also. The cortex was the essential part.

Oliver was very lucky with adrenaline, which happened to be in the extract that Schäfer injected intravenously. He had given it by mouth to his son, and adrenaline, which is an amine, is destroyed in the gut. Osler was lucky in using pigs' adrenals, because they contain more steroids than most, but he was unlucky in using glycerine as a solvent, because really active extracts were not obtained for another 30 years, when lipid solvents were used.

\section{Diabetes and the islets of Langerhans}

Diabetes in Greek means a siphon or pipe and, in the first century, Aretaeus of Cappadocia (1st c. AD; physician) described it as a melting down of the flesh and limbs into urine ${ }^{7 e}$. The Latin word mellitus means sweet, and was added later because the urine tasted like honey. There was no effective 
treatment and the disease was usually fatal within a few years, especially in young people.

The first clue to the seat of diabetes was found in 1673 when Johann Conrad Brunner (1653-1727; physician and anatomist, Diessenhofen, Switzerland) observed that a dog suffered extreme thirst and polyuria after he had removed its pancreas and spleen ${ }^{24}$. A century later (1788), Thomas Cawley (Chief Surgeon, British Forces, Jamaica), found calculi in the pancreas of a diabetic, and in 1884 Friedrich von Frerichs (1819-85; physician, Berlin), described other gross changes in the pancreas. Also in 1884, two Frenchmen, Charles Arnozan (1852-1928; physiologist, Bordeaux) and Louis Vaillard (1850-1935; microbiologist, Paris), found that ligation of the pancreatic ducts led to atrophy of the acinar tissue, while the islets remained intact. After this, events moved fast. In 1890 Joseph von Mering (1849-1908) and Oskar Minkowski (1858-1931) (chemical pathologists, Strasbourg), while studying the digestion of fat, found that diabetes followed total pancreatectomy in a dog. Minkowski then prevented the diabetes by reimplanting a portion of the excised pancreas. In 1893 Édouard Hédon (18631933; physiologist, Montpellier), found that diabetes developed when he later removed the graft, and attributed the findings to an internal secretion of the pancreas. The same year Gustave-Édouard Laguesse (1861-1927; histologist, Lille), suggested that it arose from the islet cells which had been described by Paul Langerhans (1847-88; medical student, Berlin), and that they should be named after him. He used the term "endocrine" for the first time, to distinguish their function from that of the exocrine acinar cells ${ }^{25}$. In 1893 also an attempt was made to treat a diabetic boy by transplantation of sheep's pancreas, but this was unsuccessful ${ }^{26}$. Soon, however, there was wide support for the hypothesis that diabetes was caused by lack of an internal secretion from the islets of Langerhans.

\section{Gonadectomy}

The antithesis of organotherapy with gonadal extracts was surgical ablation of the gonads or gonadectomy. This was undertaken therapeutically, without any firm rational basis, but with some very effective results. First, in 1872, Robert Battey (1828-95; surgeon, Augusta, Georgia), actually removed the ovaries for dysmenorrhoea ${ }^{27}$. Battey's operation was practised widely for neurosis and various other diseases, but fell into disrepute. In 1893 William White (1850-1916; surgeon, Philadelphia) advocated orchiec- 
tomy for prostatic hypertrophy because the testes promoted growth of the normal prostate ${ }^{28}$. Fifty years later orchiectomy was used rationally and effectively to treat prostatic cancer. In 1895 George Beatson (1849-1933; surgeon, Glasgow) suggested that the ovary and the testicle sent out "subtle and mysterious influences" and that the ovaries influenced lactation, so he undertook oöphorectomy for advanced breast cancer, with remarkable regression of the growth in one case ${ }^{29}$. Beatson's idea was sound and his operation later came to play a major part in the management of this disease.

\section{Hormones and Endocrinology}

In the nineteenth century the nervous system was thought to play the major role in coordinating bodily functions, and Ivan Pavlov (1849-1936; physiologist, St. Petersburg) stressed the importance of nervous reflexes in controlling alimentary function. At the end of the century, however, internal secretions were seen to play some part too. In 1895, just after his work with Oliver on adrenaline, Schäfer came out strongly in support of this view ${ }^{30}$. He wrote that all tissues took up materials from the blood, metabolized them and returned them to the circulating fluid. Certain glands (liver, pancreas and kidney), provided with ducts, had important external and internal secretions. Other glands (thyroid, adrenals, pituitary) had internal secretions only. (Schäfer added the pituitary to his list, because he and Oliver had just obtained a vasoactive extract from it). The study of internal secretions had a vast future, which Schäfer commended to physiologists, and he predicted that they would probably prove important therapeutically. Schäfer did not mention Brown-Séquard or organotherapy. Hunter's and Berthold's work on the testis had not yet come to light, and he stated that "without doubt" the changes following gonadectomy were produced through the nervous system. Schäfer advocated the standards of a new physiology, based on rigorous laboratory investigation.

William Bayliss (1860-1924) and Ernest Starling (1866-1927) (successors to Schäfer as Professors of Physiology, University College, London) were investigating the control of the external secretion of the pancreas in dogs, when they made a startling discovery ${ }^{31 a, b}$. It was known that acid in the duodenum stimulated the pancreas and, following Pavlov, they assumed that this involved a nervous reflex. Acid injected into the blood did not cause secretion. On 16 January 1902 they found that acid in the gut stimulated secretion by the pancreas, even when both organs were denervated, and that 
injection of an extract of jejunal mucosa mimicked the action of acid in the gut. They realized that these findings required the operation of a chemical reflex rather than a nervous one, and proposed the name "secretin" for the hypothetical chemical messenger. They conceived that secretin was a product of the intestinal mucosa, conveyed by the blood stream to the pancreas, where it stimulated the exocrine secretion by a chemical reflex. Secretin represented a new class of substances, not adequately described by the term internal secretion. In the Croonian lectures, which he gave in London in January, 1905, "On the Chemical Correlation of the Functions of the Body", Starling proposed the name "hormone" from a Greek word meaning to excite, and this was adopted generally ${ }^{32}$.

By 1905, the study of internal secretions and the organs which produced them was recognized as a new branch of biological science. For some years people debated the precise nature, properties and nomenclature of hormones, and their relations with enzymes, general metabolites, drugs, toxins, antitoxins, and vitamins, all of which had some similar features. Ten years later, in 1915, Bayliss expressed the view which prevailed eventually ${ }^{33}$. Hormones, he wrote, were produced in particular organs, were carried in the blood current, acted as chemical messengers, and influenced cell processes in distant organs. They provided chemical coordination of the organism, working side by side with that through the nervous system. The term 'endocrine', which had been proposed for the islet cell secretion 20 years before, came into general use for all hormones at about this time ${ }^{34}$. By then hundreds of papers had been published on the subject and endocrinology had embarked on the exciting voyage which is now so well known. 


\section{References}

1 Welbourn, R. B., The history of endocrine surgery, New York (Praeger) 1990. (a) 1, (b) 28-31, (c) 218, (d) 169 .

2 Rolleston, H.D., The endocrine organs in health and disease, Oxford (Oxford University Press) 1936. (a) 16-18, (b) 1, (c) 344.

3 Smith, J.A., Ross, W. D., eds., The works of Aristotle, vol. IV, Historia Animalium, books III, VIII, IX. Oxford (Clarendon Press) 1910.

4 Jørgensen, C.B., John Hunter, A.A.Berthold, and the origins of endocrinology, Acta Hist.Sci.Nat. Med. (Kbh.) 24 (1971), 1-54.

5 Addison, T., On the constitutional and local effects of disease of the suprarenal capsules, London (Samuel Highley) 1855.

6 Brown-Séquard, Ch. E., Recherches expérimentales sur la physiologie et la pathologie des capsules surrénales, Arch.gén. Med. (Paris) 8 (1856), 385-401, 572-98.

7 Major, R.H., Classic descriptions of disease, 3rd ed., Springfield, IL (Charles C. Thomas) 1945; (a) 258-62, (b) 269-72, (c) 275-9, (d) 272-4, (e) 235-7.

8 Kocher, T., Über Kropfexstirpation und ihre Folgen, Arch. klin. Chir. 29 (1883), 254-337.

9 Reverdin, J.-L., Les accidents consécutifs à l'ablation totale du goitre, Rev. méd. Suisse Romande 2 (1881), 539-40.

10 Semon, F., A typical case of myxoedema, Br. med. J. 1883/2, 1072-73.

11 Ord, W. M., Horsley, V., Semon, F. et al., Myxoedema report, Trans.clin.Soc. London 21 (1888), suppl.

12 Horsley, V., The Brown lectures, Br.med. J. 1885/1, 111-5; 211-3.

13 Sawin, C.T., Defining thyroid hormone: its nature and control, in: McCann S. M., ed., Endocrinology: people and ideas, Bethesda, MD (American Physiological Society) 1988, p. 149-99.

14 Sandström, I., Om en ny körtel hos menniskan och atskilliga döggdjur. Upsala Läk.-Fören Förh. 15 (1879-80), 441-71.

15 Munson, P. L., Parathyroid hormone and calcitonin, in: MeCann S. M., op. cit. (in ref. 13), p. 239-84.

16 Rehn, L., Über die Exstirpation des Kropfs bei Morbus Basedowii. Berl.klin. Wschr. 21 (1884), 163-6.

17 Brown-Séquard, Ch. E., The effects produced on n.an by subcutaneous injection of a liquid obtained from the testicles of animals, Lancet 1889/2, 105-7.

18 Borell, M., Organotherapy, British physiology, and the discovery of the internal secretions, J. Hist.Biol. 9 (1976), 235-68.

19 Murray, G. R., Treatment of myxoedema by injections of thyroid extract of sheep, Br.med.J. 1891/2, 796-97.

20 Fox, E. L., Myxoedema treated by extract of thyroid by mouth, Br. med.J. 1892/2, 941.

21 Oliver, G., On the therapeutic employment of the suprarenal glands, Br. med.J. 1895/2, 653-55.

22 Medvei, V.C., A history of endocrinology, Lancaster (MTP Press) 1982, 325-33, 343.

23 Osler, W., Six cases of Addison's disease, Internat. med. Magazine 5 (1896), 3-11.

24 Friesen, S. R., The endocrine gut and pancreas, in: Welbourn R. B., op. cit. (in ref. 1), 240-1. 
25 Laguesse, M.E., Sur la formation des îlots de Langerhans dans le pancréas, C.r. Soc.Biol. (Paris), 29 July 1893, 819-20.

26 Johnston, I. D. A., Islet cell transplantation, in: Welbourn R. B., Op.cit. (in ref. 1), 255.

27 Battey, R., Normal ovariotomy-case. Atlanta.med.surg. J. 10 (1872), 321-9.

28 White, J. W., The present position of the surgery of the hypertrophied prostate, Ann. Surg. 18 (1893), 152-88.

29 Beatson, G. T., On the treatment of inoperable cases of carcinoma of the mammae, Lancet 1896/2 : 104-7, 162-5.

30 Schäfer, E. A., Internal secretions, Lancet 1895/2:321-4.

31 Bayliss, W.M., Starling, E.H., (a) On the causation of the so-called "Peripheral reflex secretion" of the pancreas, Proc.R. Soc.London (Biol.) 69 (1902), 352-3; (b) The mechanism of pancreatic secretion, J. Physiol. 28 (1902), 325-53.

32 Starling, E. H., The Croonian Lectures on the chemical correlation of the function of the body, Lancet 1905/2, 339-41.

33 Bayliss, W.M., Principles of general physiology, London (Longmans Green) 1915: 706-734.

34. Sharpey-Schäfer, E., The endocrine organs, London (Longmans Green) 1916. 


\section{Zusammenfassung}

\section{Die Entwicklung der Endokrinologie}

Die Endokrinologie wurde erst zwischen 1890 und 1905 zu einem anerkannten Zweig der biologischen Wissenschaften, obwohl Ideen und Erkenntnisse seit dem Altertum dazu beigetragen haben. 1855 identifizierte Bernard Glukose als «innere Sekretion» der Leber, und Addison beschrieb die Auswirkung von Nebennieren-Erkrankungen bei Menschen. Die Entfernung der Nebennieren bei Tieren verlief tödlich.

Schon im Altertum war Kropf bekannt, und Kretinismus wurde von Paracelsus erwähnt. Myxödem wurde von Gull 1873 und Cachexia strumipriva 1883 von Kocher beschrieben. Kretinismus, Myxödem und Cachexia strumipriva wurden auf Schilddrüsenmangel zurückgeführt. Gley kam nach 1890 zur Erkenntnis, dass Tetanie nach Thyreoidektomie auf die Entfernung der Nebenschilddrüsen zurückzuführen ist. Rehn führte 1884 den M. Basedow auf Überfunktion der Schilddrüse zurück. Brown-Séquard propagierte 1889 die Verjüngung älterer Männer mit Hodenextrakt und führte 1893 eine «Organ-Therapie» ein. Murray behandelte 1891 erfolgreich Myxödem mit Schilddrüsenextrakt. Oliver bereitete 1893 einen vasoaktiven Nebennierenextrakt, und Schäfer entdeckte, dass dieser Extrakt den Blutdruck erhöhte; so wurde bald Adrenalin aus dem Nebennierenmark gewonnen. Als Ursache der Addisonschen Krankheit wurde dagegen Ausfall der Nebennierenrinde angenommen.

Diabetes mellitus verlief bis dahin normalerweise tödlich. Die Wissenschaftler des 19. Jahrhunderts kamen nun zur Einsicht, dass der Diabetes auf einem Mangel der inneren Sekretion der Langerhansschen Inseln beruhe, und Laguesse bezeichnete die Funktion dieser Inseln 1893 als «endokrin». 1895 behandelte Beatson fortgeschrittenen Brustkrebs erfolgreich mit Oophorektomie. Schäfer empfahl 1895 das Studium der Inneren Sekretion den Physiologen. 1902 entdeckten Bayliss und Starling Sekretin, einen chemischen Informationsüberträger der Darmschleimhaut. Starling schlug 1905 den Namen «Hormon» für diese Art von innerer Sekretion vor. Damit setzte sich die Endokrinologie als eine neue Sparte der Wissenschaft durch.

\section{Résumé}

\section{La naissance de l'endocrinologie}

La formation de l'endocrinologie en tant que nouvelle discipline scientifique se fit essentiellement entre 1890 et 1905, quoique des phénomènes qui s'y rattachent furent observés et interprétés depuis l'Antiquité. Au milieu du 19e siècle, en 1855, Bernard décrivit le glucose comme «sécrétion interne» du foie, et Addison rapporta les effets des maladies de la surrénale.

A partir de 1880, ce furent les séquelles de l'ablation chirurgicale de la thyroïde et des parathyroïdes qui faisaient découvrir les fonctions physiologiques de ces glandes, mais ce ne fut qu'en 1895 que le physiologiste anglais Schäfer engagea ses collègues à investiguer les sécrétions internes. 
En 1889, Brown-Séquard avait déclaré que des injections d'extrait testiculaire peuvent rajeunir les viellards; tout un système d'«organothérapie» se développa à partir de cette bonne nouvelle. En 1893, Oliver et Schäfer trouvèrent qu'un extrait de médullo-surrénale augmente la pression sanguine, ce qui amena la découverte de l'adrénaline. La maladie d'Addison, d'autre part, fut attribuée à une déficience de la corticosurrénale. Le diabète sucré fut reconnu comme résultat de l'absence de la sécrétion interne des îlots de Langerhans et en 1893, Laguesse désigna cette fonction comme «endocrine». En 1895, Beatson traita le cancer avancé du sein, avec un certain succès, par l'oophorectomie. En 1902, Bayliss et Starling découvrirent la sécrétine, un messager chimique sécrété par la muqueuse intestinale, et en 1905, Starling proposa le nom d'«hormone» pour définir cette classe de sécrétions internes. Désormais, l'endocrinologie était en marche.

Professor R. B. Welbourn

2 The Beeches

Elsley Road

GB-Tilehurst, Berks. RG3 6RQ 